\title{
Kaposi's sarcoma of the conjunctiva and the eyelid leads to the diagnosis of human immunodeficiency virus infection - a case report
}

\author{
Filipe Sousa Neves* (D, Joana Braga, João Cardoso da Costa, Joaquim Sequeira and Sandra Prazeres
}

\begin{abstract}
Background: The purpose of this case report is to describe a conjunctiva and eyelid Kaposi's sarcoma (KS) as the initial manifestation of acquired immunodeficiency syndrome (AIDS), which led to the diagnosis of HIV infection. There are only 3 reported cases of ocular KS as an initial manifestation of HIV infection.

Case presentation: A 32-year old white man presented to our department with a 1 month history of eye redness. The patient had an enlarged violet-coloured mass on the right superior eyelid which had evolved over the course of 1 week. There was also a mobile bulbar conjunctival lesion with a bright red colour, approximately $5 \mathrm{~mm} \times 5 \mathrm{~mm}$, in the superior temporal quadrant of his left eye. The lesions looked like a chalazion and a subconjunctival haemorrhage, respectivly. Presumed KS diagnosis was confirmed with HIV-1 positive testing and histopathology from tissue biopsy. The patient's CD4 count was $23 / \mathrm{mm}^{3}$ and viral RNA load $427,000 / \mathrm{ml}$. Further systemic evaluation showed a diffuse sarcoma.

Conclusion: This case report demonstrates the importance of recognizing the ocular manifestations of AIDS in establishing the correct diagnosis of KS and subsequently diagnosing occult HIV infection. Although ocular KS as the initial manifestation of HIV-AIDS is an extremely rare event, a proper diagnosis may contribute to prompt management with personal and social relevance.
\end{abstract}

Keywords: HIV, Ocular, Conjunctiva, Eyelid, Kaposi sarcoma

\section{Background}

Kaposi's sarcoma (KS) is the most common tumour in patients with the human immunodeficiency virus (HIV) infection and fully developed acquired immunodeficiency syndrome (AIDS). KS is a multifocal systemic disease related to the human herpes-virus 8 infection, found in patients with a low CD4 cell count: less than 500 cell $/ \mu$ l, typically below 200. However, ocular involvement of this endothelial malignant tumour reported as AIDS-defining illness, is an exceptionally rare event $[1,2]$.

In the literature, there is no evidence-based algorithm for the treatment of ocular KS [3]. Nevertheless, there are reports of a successful management of eyelid and

\footnotetext{
* Correspondence: filipe.neves@chvng.min-saude.pt

Department of Ophthalmology, Centro Hospitalar Vila Nova de Gaia/Espinho, Avenida Cidade de Montgeron, 212 -, 4490-402 Póvoa de Varzim, Portugal
}

conjunctiva KS with a variety of therapies (alone or in conjunction), mainly dependent on location, size, number of lesions and extra-ocular involvement. Systemic approaches include highly active antiretroviral therapy (HAART) [3-6] and chemotherapy $[4,6]$. Focal ocular lesions can be managed by surgical resection, radiation, cryotherapy or intralesional chemotherapy $[7,8]$. Nowadays, HAART is compulsory to achieve systemic disease control in HIV-AIDS patients [3].

\section{Case presentation}

A 32-year old white man presented to our department with a 1 month history of eye redness (left eye). He had already been observed by a general practitioner who advised the patient to seek ophthalmological advice if the lesion would not resolve within 3 weeks. In the first

(c) The Author(s). 2018 Open Access This article is distributed under the terms of the Creative Commons Attribution 4.0 International License (http://creativecommons.org/licenses/by/4.0/), which permits unrestricted use, distribution, and reproduction in any medium, provided you give appropriate credit to the original author(s) and the source, provide a link to the Creative Commons license, and indicate if changes were made. The Creative Commons Public Domain Dedication waiver (http://creativecommons.org/publicdomain/zero/1.0/) applies to the data made available in this article, unless otherwise stated. 
ophthalmic evaluation, the patient presented with 2 ocular lesions. These were best observed in biomicroscopy. There was an enlarged violet-coloured mass on the right superior eyelid which had evolved over the course of 1 week (Fig. 1). There was also a mobile bulbar conjunctival lesion with a bright red colour, approximately $5 \mathrm{~mm} \times 5 \mathrm{~mm}$, in the superior temporal quadrant of his left eye (Figs. 1 and 2). The patient did not mention any pain or visual changes. The lesions looked like a chalazion and a subconjunctival haemorrhage, respectively (Fig. 1). Best corrected visual acuity was 20/20 in both eyes (Snellen chart) and subsequent fundoscopic exam was normal. Patient denied previous trauma history or drug abuse. Other systemic features included facial seborrheic dermatitis (Fig. 1), a characteristic of HIV-AIDS. Past medical history was unremarkable with no serological evaluation for HIV. The main differential diagnosis at the time of presentation was blood dyscrasia, due to the duplicity of lesions. We also considered KS as part of an immunodeficiency syndrome unknown to the patient. Blood cell count and differential analysis were normal and coagulation disorders were excluded. However the HIV-1 test was found positive and the presumed diagnosis of ocular KS was established. The patient elected for an excisional biopsy of the conjunctival mass and for an incisional biopsy of the right superior eyelid. In addition, HIV-AIDS staging was performed. A CD4 cell count was determined to be $23 / \mathrm{mm}^{3}$ and the viral RNA load of $427,000 / \mathrm{ml}$. Pathologic examination confirmed KS diagnosis of both lesions. Postoperative evaluations were uneventful and no signs of recurrence were noticed during the 6-month follow-up.

Further multiple disciplinary assessments showed a diffuse KS with skin and supraglottis involvement. The patient was offered treatment for both AIDS and diffused KS. In order to achieve disease control, patient initiated systemic antiretroviral therapy - HAART - and systemic chemotherapy under medical supervision with regression of the tumour.

\section{Discussion and conclusions}

Kaposi's sarcoma is the most common neoplasm in AIDS patients $[1,2]$. However, ocular involvement leading to the HIV infection diagnosis is exceptionally atypical. To our knowledge, there are only 3 reported cases of ocular KS as

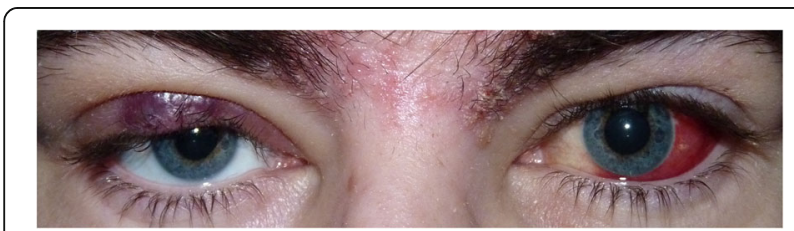

Fig. 1 Kaposi's sarcoma masquerading as a chalazion and a subconjunctival haemorrhage in the right upper eyelid and the left bulbar conjunctiva respectively

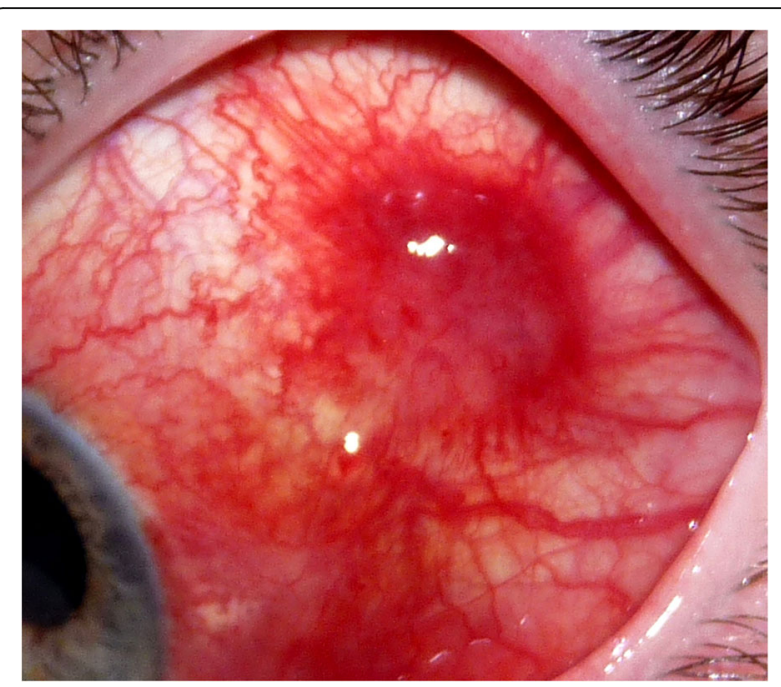

Fig. 2 Kaposi's sarcoma of the left superior temporal bulbar conjunctiva presenting as a painless red mass measuring approximately $5 \mathrm{~mm} \times 5 \mathrm{~mm}$

an initial manifestation of HIV infection. In all these reports, conjunctiva was the location of the tumour [9-11]. Nonetheless, there are also 4 cases of HIV-infected patients in which KS of the eye was the AIDS defining disease [12-15].

Fortunately, after HAART introduction in 1997, HIVAIDS patients with KS are not seen as often in occidental societies [3]. This unique tumour can be similar to a subconjunctival haemorrhage. Therefore, physicians must be aware of ocular manifestations of AIDS, as one should not misdiagnose $\mathrm{KS}$.

This case report shows the importance of accurately identifying AIDS ocular involvement. The knowledge about ocular lesions in AIDS led to the correct diagnosis of $\mathrm{KS}$ and subsequently the identification of occult HIV infection. Although ocular $\mathrm{KS}$ as the first clinical sign of HIV-AIDS is an extremely rare event, a prompt diagnosis can lead to a vital intervention in the patient's own health and utmost social relevance.

\section{Abbreviations}

AIDS: Acquired immunodeficiency syndrome; HAART: Highly active antiretroviral therapy; HIV: Human immunodeficiency virus; KS: Kaposi's sarcoma

\section{Funding}

The authors declare not to receive any type of funding to report this case.

\section{Availability of data and materials}

The datasets used and/or analysed during the current study are available from the corresponding author on reasonable request.

\section{Authors' contributions}

FSN: made a substantial contribution to the acquisition and interpretation of data; was involved in drafting the manuscript; gave approval of the version to be published; take public responsibility for appropriate portions of the content and agreed to be accountable for all aspects of the work in ensuring that questions related to the accuracy and integrity of any part of 
the work are appropriately investigated and resolved. JB: made a substantial contribution to the acquisition of data; was involved in drafting the manuscript; gave approval of the version to be published; take public responsibility for appropriate portions of the content and agreed to be accountable for all aspects of the work in ensuring that questions related to the accuracy and integrity of any part of the work are appropriately investigated and resolved. JCC: made a substantial contribution to the acquisition of data; gave approval of the version to be published; take public responsibility for appropriate portions of the content and agreed to be accountable for all aspects of the work in ensuring that questions related to the accuracy and integrity of any part of the work are appropriately investigated and resolved. JS: was involved in revising the manuscript critically for important intellectual content; take public responsibility for appropriate portions of the content and agreed to be accountable for all aspects of the work in ensuring that questions related to the accuracy and integrity of any part of the work are appropriately investigated and resolved. SP: made a substantial contribution to the acquisition of data; gave final approval of the version to be published; was involved in revising the manuscript critically for important intellectual content; take public responsibility for appropriate portions of the content and agreed to be accountable for all aspects of the work in ensuring that questions related to the accuracy and integrity of any part of the work are appropriately investigated and resolved. All authors read and approved the final manuscript.

\section{Ethics approval and consent to participate}

All procedures performed in this case report were in accordance with ethical standards of the institution and with the 1964 Helsinki declaration and its later amendments.

\section{Consent for publication}

Written informed consent for publication of their clinical details and/or clinical images was obtained from the patient. A copy of the consent form is available for review by the Editor of this journal.

\section{Competing interests}

The authors declare that they have no competing interests.

\section{Publisher's Note}

Springer Nature remains neutral with regard to jurisdictional claims in published maps and institutional affiliations.

Received: 29 January 2018 Accepted: 19 June 2018

Published online: 03 July 2018

\section{References}

1. Holland GN, Pepose JS, Pettit TH, Gottlieb MS, Yee RD, Foos RY. Acquired immunodeficiency syndrome: ophthalmic manifestations. Ophthalmology. 1983;90(8):859-73.

2. Rosenberg PR, Uliss AE, Friedland GH, Harris CA, Small CB, Klein RS. Acquired immunodeficiency syndrome: ophthalmic manifestations in ambulatory patients. Ophthalmology. 1983;90(8):874-8.

3. Mocroft A, Kirk O, Clumeck N, Gargalianos-Kakolyris P, Trocha H, Chentsova N, Antunes F, Stellbrink HJ, Phillips AN, Lundgren JD. The changing pattern of Kaposi sarcoma in patients with HIV, 1994-2003: the EuroSIDA study. Cancer. 2004;100:2644-54. https://doi.org/10.1002/cncr.20309.

4. Loke WC, Spittle MF, Mitchell S, Kulasegaram R. Timing of highly active antiretroviral therapy and chemotherapy for Kaposi's sarcoma in patients with HIV infection. Int J STD AIDS. 2006:17:565-6. https://doi.org/10.1258/ 095646206778145668.

5. Leder HA, Galor A, Peters GB, Kedhar SR, Dunn JP, Thorne JE. Resolution of conjunctival kaposi sarcoma after institution of highly active antiretroviral therapy alone. Br J Ophthalmol. 2008;92(1):151

6. Eduardo-Sánchez YW, Fernández-Agrafojo D. Human immunodeficiency virus-associated giant conjunctival Kaposi's sarcoma: complete remission with antiretroviral therapy and systemic chemotherapy. Arch Soc Esp Oftalmol. 2018;93(6):310-2. https://doi.org/10.1016/j.oftal.2017.07.010. Epub 2017 Sept 5.

7. Kohanim S, Daniels AB, Huynh N, Chodosh J. Local treatment of Kaposi sarcoma of the conjunctiva. Int Ophthalmol Clin. 2011:51(4):183-92. https://doi.org/10.1097//IO.0b013e31822d68e8.
8. Korn BS, Park DJ, Kikkawa DO. Intralesional mitomycin-C for the treatment of conjunctival Kaposi sarcoma. Ophthal Plast Reconstr Surg. 2011;27(4):e88-90. https://doi.org/10.1097//OP.0b013e3181ef72e7.

9. Schmid K, Wild T, Bolz M, Horvat R, Jurecka W, Zehetmayer M. Kaposi's sarcoma of the conjunctiva leads to a diagnosis of acquired immunodeficiency syndrome. Acta Ophthalmol Scand. 2003;81(4):411-3.

10. Curtis TH, Durairaj VD. Conjunctival kaposi sarcoma as the initial presentation of human immunodeficiency virus infection. Ophthal Plast Reconstr Surg. 2005;21(4):314-5.

11. Mika K, Pogrzebielski A, Dyduch G, Romanowska-Dixon B. Kaposi sarcoma of the conjunctiva as the first manifestation of HIV infection. Am J Case Rep. 2010;11:64-6.

12. Haye $C$, Dhermy $P$, Chic F, Schlienger $P$. Kaposi's sarcoma of the eyelid as a manifestation of AIDS. Bull Soc Ophthalmol Fr. 1987;87(2):233-6.

13. Soll DB, Redovan EG. Kaposi's sarcoma of the eyelid as the initial manifestation of AIDS. Ophthal Plast Reconstr Surg. 1989;5(1):49-51.

14. Kurumetry UR, Lustbader JM. Kaposi's sarcoma of the bulbar conjunctiva as an initial clinical manifestation of acquired immunodeficiency syndrome. Arch Ophthalmol. 1995;113(8):978.

15. Teixeira Al, Neno M, Badura R, Borges-Costa J, Filipe PL. Kaposi sarcoma of the eyelid as initial manifestation of AIDS. Dermatol Online J. 2016;15(22):7.

\section{Ready to submit your research? Choose BMC and benefit from:}

- fast, convenient online submission

- thorough peer review by experienced researchers in your field

- rapid publication on acceptance

- support for research data, including large and complex data types

- gold Open Access which fosters wider collaboration and increased citations

- maximum visibility for your research: over $100 \mathrm{M}$ website views per year

At BMC, research is always in progress.

Learn more biomedcentral.com/submissions 